\title{
Health related quality of life in patients with Cohn's disease in remission
}

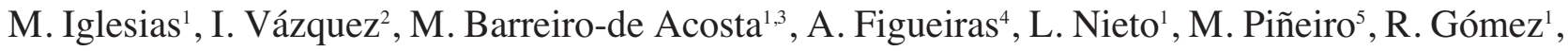 \\ A. Lorenzo ${ }^{3}$ and J. E. Domínguez-Muñoz ${ }^{1,3}$ \\ ${ }^{1}$ Fienad Clinic University Hospital of Santiago. ${ }^{2}$ Departament of Clinic Psycology and Psicobiology. Univertity of \\ Santiago. ${ }^{3}$ Digestive Department Clinic Hospital of Santiago. ${ }^{4}$ Preventive Medicine and Public Health. University of \\ Santiago. ${ }^{5}$ CIBER of Epidemiology and Public Health. Spain
}

\begin{abstract}
Background: Crohn's disease (CD) affects Health Related Quality of Life (HRQoL) especially in patients with clinical activity but their impact over the disease during periods of remission has not been sufficiently studied.

Objective: To evaluate $\mathrm{HRQ} \mathrm{OL}$ in $\mathrm{CD}$ patients in remission and to identify socio-demographic and clinical factors related.

Methods: We included patients with $\mathrm{CD}$ in remission for at least 6 months, defined as a CDAI $<150$ and a CRP $<5 \mathrm{mg} / \mathrm{L}$. Socio-demographic and clinical parameters were recorded. HRQoL was evaluated with Short Form 36 Questionnaire (SF-36) and the Inflammatory Bowel Disease Questionnaire (IBDQ). Results were analyzed using multiple regressions with a confidence interval of 95\%.

Results: Nine two patients $(\bar{X}=37 \pm 11.4$ years, $52.2 \%$ men $)$ were consecutively included. Two patients failed to fill correctly the questionnaire and were excluded. Scores on the SF-36 were lower than in the general population of similar age and gender. The most affected dimension in the SF-36 was General Health $(47.98 \pm 19.58)$ and the IBDQ Systemic Symptoms (5.15 \pm 1.27). Age, colonic location and previous surgery was related with worse HRQoL, while higher educational status, more time since diagnosis, steroid-resistance and inflammatory behavior, was associated with better HRQoL.

Conclusions: Despite being in remission, CD patients had affected their HRQoL, so we must continue working to achieve improvement in HRQL of these patients during these periods of the disease.
\end{abstract}

Key words: Crohn's disease. Health related quality of life. Remission.

\section{RESUMEN}

Introducción: La enfermedad de Crohn (EC) afecta la Calidad de Vida Relacionada con la Salud (CVRS) en las fases de actividad pero el impacto de esta enfermedad en la CVRS durante los períodos de remisión no ha sido suficientemente estudiada.

Objetivo: Evaluar la CVRS en pacientes con EC en remisión e identificar los factores sociodemográficos y clínicos relacionados.

Métodos: Se incluyeron pacientes adultos con EC en remisión durante al menos 6 meses, definida con un CDAI $<150$ y una $\mathrm{PCR}<5 \mathrm{mg} / \mathrm{L}$. Se recogieron datos sociodemográficos, clínicos y de CVRS con los cuestionarios Short Form 36 Questionnaire (SF-36) y The Inflammatory Bowel Disease Questionnaire (IBDQ). Los resultados fueron analizados mediante regresión múltiple con un intervalo de confianza del 95\%.

Resultados: Se incluyeron consecutivamente 92 pacientes ( $\bar{X}=37 \pm 11,4$ años; $52,2 \%$ varones). 2 pacientes no cumplimentaron adecuadamente los cuestionarios. Las puntuaciones en el SF-36 fueron inferiores a las de la población general de similar edad y sexo. La dimensión más afectada en el SF-36 fue Salud General $(47,98 \pm 19,58)$ y en el IBDQ Síntomas Sistémicos $(5,15$ $\pm 1,27$ ). La mayor edad, la localización colónica y la cirugía previa se relacionaron con una peor CVRS, mientras que mayor nivel de estudios, mayor tiempo desde el diagnóstico, patrón inflamatorio y corticorresistencia se asociaron con una mejor CVRS.

Conclusiones: A pesar de encontrarse en período de remisión los pacientes EC presentan afectada su CVRS, por lo que se debe continuar trabajando en la consecución de la mejora en la CVRS de estos enfermos durante esta fase de la enfermedad.

Palabras clave: Enfermedad de Crohn. Calidad de vida relacionada con la salud. Remisión.
Received: 09-02-10.

Accepted: 20-04-10.

Correspondence: Manuel Barreiro de Acosta. Servicio de Aparato Digestivo. Hospital Clínico Universitário. C/ Choupana, s/n. 15706 Santiago de Compostela. A Coruña, Spain.e-mail: manubarreiro@hotmail.com
Iglesias M, Vázquez I, Barreiro-de Acosta M, Figueiras A, Nieto L, Piñeiro M, Gómez R, Lorenzo A, Domínguez-Muñoz JE. Health related quality of life in patients with Cohn's disease in remission. Rev Esp Enferm Dig 2010; 102: 624-630. 


\section{INTRODUCTION}

Crohn's disease (CD) is an inflammatory bowel disease of unknown etiology (1), which presents clinically alternating periods of flare and remission (2), and its clinical characteristics (chronic nature and unpredictable course, extraintestinal manifestations, possible side effects of some treatments, need for surgery, etc.) could affect to health related quality of life (HRQoL) of people who suffer from this disease $(3,4)$.

Among the determining factors in the impairment of HRQoL in CD, the disease activity has been identified as one of the most important (5) for both dimensional modular pattern of damage (6) as its magnitude (7). However, the effect of clinical recovery of these patients on HRQoL has received poor attention and remains unable to determine the profile and degree of impairment of HRQoL during this phase of the disease (8). Some studies notified that HRQoL in patients with CD in remission is similar to the general population (9-12) while in other HRQoL is lower than the general population $(13,14)$

Although it had been studied the effect of different demographic factors (gener, age or educational level) (15) and clinical (type of treatment, therapeutic effectiveness, presence of extraintestinal manifestations, number of relapses per year, severity or need of hospitalizations) (16) on the HRQoL of these patients, there is some confusion about the specific contribution of each of them (17), particularly when patients are in remission. The recognition of these factors would be of interest for a correct assessment and intervention on HRQoL in remission.

The aim of this study was to evaluate the HRQoL in patients with $\mathrm{CD}$ in remission and to assess the potential socio-demographic and clinical factors that are related to the quality of life estimated during this phase of disease.

\section{METHODS}

We included consecutively patients with $\mathrm{CD}$ who attended the specialized Inflammatory Bowel Disease Unit at the University Hospital of Santiago de Compostela, Spain. For the selection of patients established the following inclusion criteria: diagnosis of $\mathrm{CD}$ according to the criteria of Lennard-Jones (18), age over 18 years, being in clinical remission in the previous 6 months, defined by a Crohn's Disease Activity Index (CDAI) (19) below 150, a Harvey-Bradshaw (20) of 3 or lower with a value of C-reactive protein (CRP) value less than $5 \mathrm{mg} / \mathrm{L}$, and have no cognitive problems would prevent the subject from completing the questionnaires correctly.

All patients recorded the following demographic data: gender, age, cohabitation status, education level, smoking; and clinicians: age at diagnosis of $\mathrm{CD}$, years since diagnosis, the different phenotypes of the Montreal Classification (21) considering location (ileal, colonic, ileocolonic) and pattern (inflammatory, stricturing, fistuliz- ing), extraintestinal manifestations (presence/absence), perianal disease, corticosteroid dependency and corticosteroid resistance as defined by the ECCO (22). We evaluated the treatment used for the maintenance of remission (biological vs. non-biological therapies) and other concomitant medications.

To evaluate the HRQoL of patients with inflammatory bowel disease using two instruments: a generic questionnaire The Short Form-36 Health Survey (SF-36) and a specific questionnaire The Inflammatory Bowel Disease Questionnaire (IBDQ).

The SF-36 (23) consists of 36 items grouped into 8 scales: physical function, role physical, bodily pain, general health, vitality, social function, role emotional, mental health. The scale scored from $0-100$, with 0 being the worst score possible.

The IBDQ is a specific HRQoL questionnaire for IBD. In this study we used the version of Love et al. (24) consisted of 36 items distributed in five dimensions: bowel symptoms, systemic symptoms, social impairment, emotional function and functional impairment. Each question is answered with the same 7-point Likert Scale $(1=$ worst HRQoL).

In this study we used the Spanish population adapted versions of the SF-36 (25) and IBDQ (26), which both showed good psychometric properties $(25,26)$.

The gastroenterologist collected the clinical data of interest and then the patients were seen by the psychologist, who collected demographic data and administered HRQoL questionnaires. Data collection took place between April and November 2008.

The study was approved by the Ethical Committee of Clinical Research of Galicia.

The description of the socio-demographic and clinical characteristics of the sample HRQoL was performed using frequencies for categorical variables and mean and standard deviation for quantitative data. To examine more exactly the effects of $\mathrm{CD}$ in the estimation of generic dimensions of HRQoL controlling for age and sex, the scores were standardized using the method proposed by the authors of the SF-36 (23), using the normative data of the Spanish population (27).

In the case of IBDQ we have been used only direct scores obtained in each of the dimensions because this is a specific instrument of HRQoL.

To identify demographic and clinical variables influencing the different aspects of HRQoL bivariate statistical models were created between each variable and the different scales of the SF-36 and IBDQ. Those factors that were statistically significant in the bivariate analysis were included on multiple regression models with each of the dimensions of the questionnaires as dependent variables. They were then eliminated in succession model those independent variables were not significant and did not substantially alter the coefficients of other independent variables. Statistically significant was considered at $5 \%$. We had been used SPSS version 13.00 (SPSS Inc., Chicago, IL, USA). 


\section{RESULTS}

The sample consisted of 92 patients (48 males, $52.2 \%$ ) between $18-71$ years $(\bar{X}=37.6 \pm 11.4)$. Demographic and phenotypic characteristics (according to Montreal classification) are summarized in table I.

Table I. Patients socio-demographic and clinical characteristics according to the Montreal Classification

\begin{tabular}{|c|c|}
\hline $\operatorname{Sex} N(\%)$ & $\begin{array}{l}44 \text { female ( } 47 \\
48 \text { male ( } 52 .\end{array}$ \\
\hline $\begin{array}{l}\text { Age (years) mean } \pm \text { ST (range) } \\
\text { Age at diagnosis mean } \pm \text { ST } \\
\text { Years of disease mean } \pm \text { ST } \\
\text { Marital Status N }(\%)\end{array}$ & $\begin{array}{l}37.6 \pm 11.4(1 \\
27.9 \pm 10.6 \\
9.2 \pm 8.1 \\
42 \text { with no pe } \\
50 \text { with partn }\end{array}$ \\
\hline Education N (\%) & $\begin{array}{l}1 \text { with no ed } \\
44 \text { primary (4 } \\
31 \text { secondary } \\
16 \text { higher (17 }\end{array}$ \\
\hline Tobacco consumption $\mathrm{N}(\%)$ mean $\pm \mathrm{ST}$ & $\begin{array}{l}30 \text { smokers } \\
24 \text { ex-smoker } \\
38 \text { non- smok }\end{array}$ \\
\hline $\begin{array}{l}\text { Montreal Classification } \\
\text { Age } N(\%) \\
\text { A1 }(<16) \\
\text { A2 }(16 \text { a } 40) \\
\text { A3 }(>40)\end{array}$ & $\begin{array}{l}0(0.0 \%) \\
60(65.2 \%) \\
32(34.8 \%)\end{array}$ \\
\hline $\begin{array}{l}\text { Behavior N (\%) } \\
\text { B1 (Inflammatory) } \\
\text { B2 (Stenosing) } \\
\text { B3 (Fistulizing) } \\
\text { Perianal }\end{array}$ & $\begin{array}{l}40(43.5 \%) \\
23(25.0 \%) \\
29(31.5 \%) \\
25(27.2 \%)\end{array}$ \\
\hline $\begin{array}{l}\text { Location N (\%) } \\
\text { L1 (lleal) } \\
\text { L2 (Colonic) } \\
\text { L3 (lleocolonic) } \\
\text { L4 (Upper tract) }\end{array}$ & $\begin{array}{l}44(47.8 \%) \\
10(10.9 \%) \\
38(41.3 \%) \\
0(0.0 \%)\end{array}$ \\
\hline
\end{tabular}

With regard to the patient's clinical characteristics $45.7 \%$ of the total, had extraintestinal manifestations (EM), 27.5\% had undergone previous intestinal resection associated to the EC, while $40.2 \%$ and $44.6 \%$ had previously developed corticosteroid dependency and corticosteroid resistance, respectively. As maintenance therapy for remission, $46.8 \%$ received biological therapies (34.8\% infliximab and $12 \%$ adalimumab) while $53.3 \%$ were non-biological therapies.

Of the 92 patients who agreed to participate, two $(2.2 \%)$ did not complete the questionnaires correctly and therefore were considered scores of SF-36 and IBDQ of 90 patients.

The analysis of the impact of the $\mathrm{CD}$ in generic dimensions indicated that the most affected was general health $(\bar{X}=47.98 \pm 19.58)$, while the least affected were physi- cal function $(\bar{X}=81.52 \pm 23.48)$ and social function $(\bar{X}=$ $77.07 \pm 25.78)$. In this case, differences between biologics $v s$. non biologics only were significant in physical function. With regard to specific dimensions, the patients perceived the greatest impact on systemic symptoms $(\bar{X}=$ $5.15 \pm 1.20)$ while social impairment $(\bar{X}=5.95 \pm 1.06)$ was the least impairment. Table II shows the scores on the SF-36 and IBDQ.

\begin{tabular}{lccc}
\multicolumn{4}{c}{ Table II. Scores on health related quality of life in our } \\
sample
\end{tabular}

When controlling for age and sex to estimate the effect of the disease, CD patients scored lower in all SF-36 scales than general population, being general health the most impairment, and mental health and role physical the least (Fig. 1).

In multivariate statistical models for the SF-36, older age was associated with lower scores on mental health and vitality ( $\mathrm{p}=0.026$ and $\mathrm{p}<0.001$ respectively), being mar-

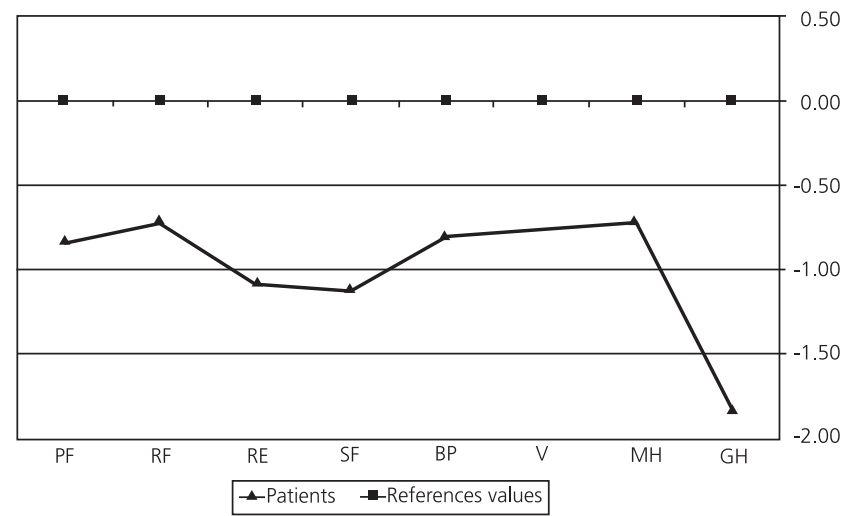

Fig. 1. Standardized scores of the questionnaire SF-36. PH: physical function; RF: role physical; RE: role emotional; SF: social function; BP: bodily pain; V: vitality; $\mathrm{MH}$ : mental health; $\mathrm{GH}$ : general health. 
ried/ living with partner was associated with lower scores on bodily pain $(p=0.009)$ and the highest level of education (university level) with better scores on general health $(p=0.015)$. Among clinical variables, the corticosteroid resistance was associated with better scores on role physical $(p=0.016)$, more years since diagnosis with better scores on vitality $(\mathrm{p}=0.002)$, bodily pain $(\mathrm{p}=0.013)$ and mental health $(\mathrm{p}=0.022)$, colonic location with lower scores on vitality $(p=0.044)$ and previous surgery with lower scores on role emotional $(\mathrm{p}=0.010)$ (Table III).

In the IBDQ, older was associated with worse scores on functional impairment $(\mathrm{p}=0.004)$, highest level of education (university education) was associated with better scores on emotional function $(p=0.048)$ more years since diagnosis and inflammatory pattern was associated with better scores in systemic symptoms $(p=0.028)$ and functional impairment $(\mathrm{p}=0.045)$ respectively (Table IV).

\section{DISCUSSION}

This study shows that HRQoL of CD patients in remission is affected and does not reach values similar to the general population. The socio-demographic characteristics: age, educational level, living situation, and clinics: years since diagnosis, location, pattern, corticosteroid resistance and previous surgery were the variables associated with HRQoL in these patients.

The assessment of HRQoL was performed with two types of instruments: a generic questionnaire (SF-36) that allows for comparison with the general population, and a specific questionnaire (IBDQ), which enables to establish the specific domains affected these patients, thus providing a more precise characterization of the profile of disease impact (28).

The data obtained with the SF-36, when compared with population reference values; show that although CD patients in our sample were in remission, their quality of life scores are lower in all dimensions than general population of the same age and gender. These results are consistent with those reported in previous studies $(13,14,29)$ but contradict those found in others (9-12). Given that we included a relatively high percentage of patients in serious or high risk $(46.7 \%$ are receiving maintenance treatment with biological therapies) it is likely that impairment of HRQoL in these patients come derived from a

Table III. Model results of multiple regression analysis taking each of the scales of the SF-36 as the dependent variable

\begin{tabular}{|c|c|c|c|c|c|c|c|c|}
\hline & GH & PF & $R F$ & V & $R E$ & SF & $B P$ & $M H$ \\
\hline $\begin{array}{l}\text { Gender } \\
\text { Age } \\
\text { University Education } \\
\text { Married/living with a partner } \\
\text { Cig/day } \\
\text { Years of disease } \\
\text { Previous Surgery } \\
\text { Colonic Location } \\
\text { Inflammatory Pattern } \\
\text { Perianal } \\
\text { Corticosteroid dependence } \\
\text { Corticosteroid resistance }\end{array}$ & $\begin{aligned} & T=1.438 ; n . S . \\
& T=-0.273 ; n . s . \\
& T=2.489 ; p=0.015 \\
& T=-0.567 ; n . s . \\
& T=0.523 ; n . s . \\
& T=-0.527 ; n . s . \\
& T=-0.560 ; n . s . \\
& T=-0.209 ; n . s . \\
& T=0.446 ; n . s . \\
& T=0.478 ; n . s . \\
& T=0.535 ; n . S . \\
& T=1.377 ; n . s .\end{aligned}$ & $\begin{array}{l}T=1.151 ; n . s . \\
T=-1.965 ; n . s . \\
T=1.492 ; n . s . \\
T=1.287 ; n . s . \\
T=0.321 ; n . s . \\
T=1.403 ; n . s . \\
T=-0.041 ; n . s . \\
T=0.175 ; n . s . \\
T=0.427 ; n . s . \\
T=1.011 ; n . s . \\
T=-0.977 ; \text { n.s. } \\
T=-0.049 ; \text { n.s. }\end{array}$ & $\begin{aligned} & T=0.916 ; n . s . \\
& T=0.10 ; n . s . \\
& T=0.573 ; n . s . \\
& T=-1.210 ; n . s . \\
& T=1.135 ; n . s . \\
& T=0.713 ; n . s . \\
& T=-1.717 ; n . s . \\
& T=1.319 ; n . s . \\
& T=1.680 ; n . s . \\
& T=0.779 ; n . s . \\
& T=-1.145 ; n . s . \\
& T=2.473 ; p=0.016\end{aligned}$ & $\begin{array}{c}T=-0.041 ; n . s . \\
T=-3.461 ; p=0.001 \\
T=0.783 ; n . s . \\
T=-0.918 ; n . s . \\
T=1.251 ; n . s . \\
T=3.248 ; p=0.002 \\
T=0.265 ; n . s . \\
T=-0.216 ; p=0.044 \\
T=0.489 ; n . s . \\
T=0.150 ; n . s . \\
T=-1.311 ; n . s . \\
T=-0.287 ; n . s .\end{array}$ & $\begin{aligned} & T=-0.260 ; n . s . \\
& T=-0.624 ; n . s . \\
& T=-0.003 ; n . s . \\
& T=-1.065 ; n . s . \\
& T=-0.054 ; n . s . \\
& T=1.910 ; n . s . \\
& T=-2.657 ; p=0.010 \\
& T=-1.558 ; n . s . \\
& T=1.630 ; n . s . \\
& T=1.883 ; n . s . \\
& T=-1.278 ; n . S . \\
& T=1.103 ; n . s .\end{aligned}$ & $\begin{array}{l}T=0.435 ; n . s . \\
T=0.394 ; n . s . \\
T=0.058 ; n . s . \\
T=0.721 ; n . s . \\
T=0.211 ; n . s . \\
T=-0.340 ; \text { n.s. } \\
T=-0.539 ; n . s . \\
T=0.022 ; n . s . \\
T=1.665 ; n . s . \\
T=1.513 ; n . s . \\
T=0.201 ; n . s . \\
T=1.438 ; n . s .\end{array}$ & $\begin{aligned} & T=0.012 ; n . s . \\
& T=-1.468 ; n . s . \\
& T=0.569 ; n . s . \\
& T=-2.686 ; p=0.009 \\
& T=-0.077 ; n . s . \\
& T=-0.280 ; p=0.009 \\
& T=0.101 ; n . s . \\
& T=-1.265 ; n . s . \\
& T=0.578 ; n . s . \\
& T=0.256 ; n . s . \\
& T=-0.880 ; \text {. } \\
& T=0.745 ; \text { n. }\end{aligned}$ & $\begin{aligned} & T=0.323 ; n . s . \\
& T=-2.265 ; p=0.026 \\
& T=-0.449 ; n . s . \\
& T=-0.468 ; n . s . \\
& T=-0.521 ; n . s . \\
& T=2.334 ; p=0.022 \\
& T=-0.217 ; n . s . \\
& T=-2.060 ; n . s . \\
& T=0.933 ; n . s . \\
& T=-0.330 ; n . s . \\
& T=-1881 ; n . s . \\
& T=0.503 ; n . s .\end{aligned}$ \\
\hline
\end{tabular}

GH: general health; PF: physical function; RF: role physical; V: vitality; RE: role emotional; SF: social function; BP: bodily pain; MH: mental health.

Table IV. Model results of multiple regression analysis taking each of the dimensions of the IBDQ as the dependent variable.

\begin{tabular}{|c|c|c|c|c|c|}
\hline & $B S$ & SS & SI & $E F$ & $\mathrm{Fl}$ \\
\hline Sex & $T=1.548 ; n . s$. & $T=1.308 ; n . s$. & $T=0.780 ; n . s$ & $T=1.606 ;$ n.s. & $T=0.613 ;$ n.s. \\
\hline Age & $\mathrm{T}=0.921 ;$ n.s. & $T=-1.412 ; n . s$. & $T=-0.654 ;$ n.s. & $T=-0.475 ;$ n.s. & $T=-2.998 ; p=0.004$ \\
\hline University education & $T=0.974 ;$ n.s. & $\mathrm{T}=2.050 ;$ n.s. & $T=1.718 ;$ n.s. & $T=2.007 ; p=0.048$ & $T=1.244 ;$ n.s. \\
\hline Married/living with a partner & $T=-0.918 ;$ n.s. & $T=-0.204 ; n . s$. & $T=0.146 ; n . s$. & $T=-0.635 ;$ n.s. & $T=-0.213 ;$ n.s. \\
\hline Cig/day & $T=-0.170 ;$ n.s. & $T=-0.843 ;$ n.s. & $T=-0.543 ;$ n.s. & $T=-0.325 ; n . s$. & $T=-0.246 ;$ n.s. \\
\hline Years of disease & $T=0.825 ;$ n.s. & $T=2.239 ; p=0.028$ & $T=0.658 ; n . s$. & $T=0.485 ;$ n.s. & $T=1.595 ;$ n.s. \\
\hline Previous Surgery & $\mathrm{T}=-0.942 ;$ n.s. & $T=0.567 ;$ n.s. & $T=0.052 ;$ n.s. & $T=0.305 ;$ n.s. & $T=-0.095 ;$ n.s. \\
\hline Colonic location & $\mathrm{T}=0.449 ;$ n.s. & $T=-0.186 ; n . s$. & $T=-0.259 ;$ n.s. & $T=1.096 ; n . s$. & $T=-0.598 ; n . s$. \\
\hline Inflammatory pattern & $\mathrm{T}=1.951 ;$ n.s. & $T=0.147 ;$ n.s. & $T=0.968 ; n . s$. & $T=1.356 ; n . s$. & $T=2.032 ; p=0.045$ \\
\hline Perianal & $\mathrm{T}=1.837 ;$ n.s. & $T=0.552 ; n . s$ & $T=0.708 ; n . s$. & $T=1.044 ;$ n.s. & $T=1.862 ; n . s$ \\
\hline Corticosteroid dependence & $\mathrm{T}=0.167 ;$ n.s. & $T=-1.543 ;$ n.s. & $T=-0.551 ; n . s$. & $T=-1.246 ;$ n.s. & $T=-0.430 ; n . s$. \\
\hline Corticosteroid resistance & $\mathrm{T}=0.837 ;$ n.s. & $T=-0.554 ; n . s$. & $T=0.881 ; n . s$. & $\mathrm{T}=0.492 ;$ n.s. & $T=0.582 ; n . s$. \\
\hline
\end{tabular}

BS: Bowel symptoms; SS: systemic symptoms; SI: social impairment; EF: emotional function; Fl: functional impairment 
previous seriously situation, even when they were in clinical remission clearly defined. In fact, in this same population we also observed that despite the inactivity of the disease, patients had a high psychological morbidity (30).

Regarding the profile of impairment, we found that the scale general health of SF-36 questionnaire is the most impairment if we consider both the direct and the standardized scores, showing as one of the most important indicators of the effect of CD on HRQoL. This finding is consistent with previous literature $(28,31)$ and emphasizes the fact that asymptomatic patient continues to perceive their health status strongly affected in relation to what would be expected based on their age and sex.

In the IBDQ, the systemic symptoms were the most affected dimension in concordance with previously reported $(4,12)$. Possibly non-specific symptoms of the disease as fatigue, discomfort, irritability, appetite and energy issues become more prominent after bowel symptoms remit (12).

Furthermore, older patients, living with a partner, the colonic location and previous surgery were negatively related to HRQoL while higher studies, greater time since diagnosis, corticosteroid resistance, and inflammatory pattern were positively associated with HRQoL. In accordance with previous researches, gender (32-34), tobacco consumption (17), previous relapses and area of residence (4) did not affect the quality of life.

Older age was related to worse vitality and mental health of the SF-36 and functional impairment of the IBDQ. The impact of age on quality of life has been reported in other studies $(5,31)$ and it could be explained by increased comorbidity (35) and impairment associated with age (36), so is not specific of IBD because it have been found in other chronic diseases (37-39).

Another independent factor identified in this study was the educational level. This variable was positively associated with general health and emotional function. The relationship between high educational level and better quality of life has been reported previously in general population (40) and IBD $(5,41)$, and could be explained by its correspondence with higher socioeconomic status (42) greater ability to access information about the disease and have more skills and resources.

Colonic location was associated to lower scores on vitality and inflammatory pattern, with better scores on functional impairment. These findings are not supported in some previous researches $(5,43)$, however colonic location has been negatively associated with quality of life in previous studies (44), and in concordance with other researches, our results suggest that fistulizing forms are more disabling than inflammatory forms (45) because they limit carry out everyday activities.

It is interesting to emphasize that a longer duration of disease is associated with greater vitality, less bodily pain and systemic symptoms, in concordance with the results of Casellas et al. (4), suggesting that during the course of the disease the patients probably would undertake a process of adaptation to the symptoms.
An unexpected finding in this study was the positive relationship found between physical role and corticosteroid resistance. A possible explanation is that patients with corticosteroid resistance experience a major change from their previous situation and asses this positively, because now they can do things that previously could not. We considerer that question should be further explored in the future.

Finally, previous surgery was negatively correlated with role emotional. Although the improvement quality of life has been reported in patients with $\mathrm{CD}$ after surgery $(46,47)$, some studies report that long-term, patients who often have undergone surgery, have poorer HRQoL $(17,48)$. Must be taken into account that surgery is employed when medical treatment fails, so maybe the patient is more emotionally affected.

We consider some limitations in our study: first we did not know the HRQoL reported by the patients prior to clinical remission and we have a small sample size. Likewise, as a cross-sectional study we can not establish causal relationships, requiring longitudinal studies for that.

In conclusion, the HRQoL in CD patients is affected even if the disease is not active, particularly in older patients, low education, colonic location and previous surgery. Given that HRQoL is an important therapeutic target in IBD, we must continue paying attention to $\mathrm{CD}$ patients in remission to provide them a global care.

\section{REFERENCES}

1. Fiocchi C. Inflammatory Bowel Disease: Etiology and pathogenesis. Gastroenterology 1998; 115: 182-205.

2. Vermeire S, van Assche G, Rutgeerts P. Altering the Natural History of Cronh's Disease Evidence for and Against Current Therapies. Aliment Pharmacol Ther. 2007; 25: 3-12.

3. Casellas F, López-Vivancos J, Vergara M, Malagelada J. Impact of inflammatory bowel disease on health-related quality of life. Dig Dis 1999; 17: 208-18.

4. Casellas F, Arenas JI, Baudet JS, Fábregas S, García N, Gelabert J, et al. Impairtment of health-related quality of life in patients with inflammatory bowel disease: a Spanish multicenter study. Inflamm Bowel Dis 2005; 11: 488-96.

5. Casellas F, López-Vivancos J, Casado A, Malagelada JR. Factors affecting health related quality of life on patients with inflammatory bowel disease. Qual Life Res. 2002; 11: 775-81.

6. Casellas F, López-Vivancos J, Badía X, Vilaseca J, Malagelada JR. Influence of inflammatory bowel disease on different dimensions of quality of life. Eur J Gastroenterol Hepatol 2001; 13: 567-72.

7. Irvine EJ, Grace E, Kerr JD, Lyrenas E, Bolin C, O’Morain, et al. Non-disease related factors affecting health related quality of life (HRQOL) in inflammatory bowel disease (IBD). Gastroenterology 1998; 114: A1002.

8. Casellas F, Rodrigo L, Pantiga C, Riestra S, Malagelada JR. Sustained Improvement of Health-Related Quality of Life in Crohn's Disease Patients Treated with Infliximab and Azathioprine for 4 Years. Inflamm Bowel Dis 2007; 13: 1395-400.

9. Lichtenstein GR, Yan S, Bala M, Hanauer S. Remission in patients with Crohn's disease is associated with improvement in employment and quality of life and a decrease in hospitalizations and surgeries Am J Gastroenterol 2004; 99: 91-6.

10. Andersson P, Olaison G, Bendtsen P, Myrelid P, Sjödahl R. Health related quality of life in Crohn's proctocolitis does not differ from a 
general population when in remission. Colorectal Dis 2003; 5: 56-62.

11. Simrén M, Axelsson J, Gillberg R, Abrahamsson H, Svedlund J, Björnsson S. Quality of life in inflammatory bowel disease in remission: the impact of IBS-like symptoms and associated psychological factors. Am J Gastroenterol 2002; 97: 389-96.

12. Calvet X, Gallardo O, Coronas R, Casellas F, Montserrat A, Torrejón A, et al. Remission on Thiopurinic Immunomodulators Normalizes Quality of Life and Psychological Status in Patients with Crohn's Disease. Inflamm Bowel Dis 2006; 12: 692-6.

13. Martin A, Leone L, Fries W, Naccarato R. Quality of Life in inflammatory bowel disease. Ital J Gastroenterol 1995; 27: 450-4.

14. Verma S, Tsai HH, Giaffer MH. Does better disease-related education improve quality of life?. A survey of IBD patients. Dig Dis Sci 2001; 46: 865-9.

15. Irvine EJ, Feagan B, Rochon J, Archambault A, Fedorack RN, Groll A, et al. Quality of life: a valid and reliable measure of therapeutic efficacy in the treatment of inflammatory bowel disease. Gastroenterology 1994; 106: 287-96.

16. Casellas F, López-Vivancos J, Badia X, Vilaseca J, Malagelada JR. Impact of surgery for Crohn's disease on health-related quality of life. Am J Gastroenterol 2000; 95: 177-82.

17. López-Blanco B, Moreno-Jiménez B, Devesa Múgica JM, Rodríguez Muñoz A. Relación entre variables sociodemográficas y clínicas y calidad de vida relacionada con la salud en pacientes con enfermedad inflamatoria intestinal. Rev Esp Enferm Dig 2005; 97: 893-8.

18. Lennard-Jones. Classification on inflammatory bowel disease. Scand J Gastroenterol 1989; 24: 2-6.

19. Best WR, Becktel JM, Singleton JW, Kern F Jr. Development of a Crohn's disease activity index. National Cooperative Crohn's Disease Study. Gastroenterology 1976; 70: 439-44.

20. Harvey R, Bradshaw J. A simple index of Crohn's-disease activity. Lancet 1980; 315: 514.

21. Silverberg M, Satsangi J, Ahmad T, Arnott I, Bernstein Ch, Brandt $\mathrm{SR}$, et al. Toward and integrated clinical, molecular, and serological classification of inflammatory bowel disease: report or a working party of the Montreal World Congress of Gastroenterology. Can J Gastroenterol 2005; 19: 5A-36A.

22. Stange EF, Travis SP, Vermeire S, Beglinger C, Kupcinkas L, Geboes K, et al. European evidence based consensus on the diagnosis and management of Crohn's disease: definitions and diagnosis. Gut 2006: 55 Supl 1: i1-15.

23. Ware JE, Sherbourne CD: The MOS-36 item short form health survey (SF-36). I. Conceptual framework and item selection. Med Care 1992; 30: 473-83

24. Love JR, Irvine EJ, Fedorak RN. Quality of life in IBD. J Clin Gastroenterol 1992; 14: 15-9.

25. Alonso J, Prieto L, Antó JM. La versión española del SF-36 Health Survey (Cuestionario de Salud SF-36): un instrumento para la medida de los resultados clínicos. Med Clin (Barc). 1995; 104: 771-6.

26. López Vivancos J, Casellas F, Badía X, Vilaseca J, Malagelada JR. Validation of the Spanish version of the Inflammatory Bowel Disease Questionnaire on Ulcerative Colitis and Crohn's Disease. Digestion 1999; 60: 274-80.

27. Alonso J, Regidor E, Barrio G, Prieto L, Rodríguez C, de la Fuente L. Valores poblacionales de referencia de la versión española del Cuestionario de Salud SF-36. Med Clin (Barc) 1998; 111: 410-6.

28. McColl E, Han SW, Barton JR, Welfare MR. A comparison of the discriminatory power of the Inflammatory Bowel Disease Questionnaire and the SF-36 in people with ulcerative colitis. Qual Life Res 2004; 13: 805-11

29. Graff LA, Walker JR, Lix L, Clara I, Rawsthorne P, Rogala L, et al. The Relationship of Inflammatory Bowel Disease Type and Activity to Psychological Functioning and Quality of Life. Clin Gastroenterol Hepatol. 2006; 4: 1491-501.

30. Iglesias M., Barreiro de Acosta M., Vázquez I., Figueiras A., Nieto L., Lorenzo A. et al. Impacto psicológico de la enfermedad de Crohn en pacientes en remisión: riesgo de ansiedad y depresión. Rev Esp Enferm Dig. 2009: 101: 249-57.

31. Bernklev T, Jahnsen J, Lygren I, Henriksen M, Vatn M, Moum B Health-related quality of life in patients with inflammatory bowel disease measured with the Short-Form-36: Psychometric assessments and a comparison with a general population norms. Inflamm Bowel Dis 2005; 11: 909-18.

32. Zahn A, Hinz U, Karner M, Ehehalt R, Stremmel W. Health related quality of life correlates with clinical and endoscopic activity indexes but not with demographic features in patients with ulcerative colitis Inflamm Bowel Dis 2006; 12: 1058-67.

33. Han SW, McColl E, Barton JR, James P, Steen IN, Welfare MR. Predictors of quality of life in ulcerative colitis: The importance of symptoms and illness representations. Inflamm Bowel Dis 2005; 11 : 24-34.

34. Gibson PR, Weston AR, Shann A, Florin THJ, Lawrance IC, Macrae FA, et al. Relationship between disease severity, quality of life and health-care resource use in a cross-section of Australian patients with Crohn's disease. J Gastroenterol Hepatol. 2007; 22: 1306-12.

35. Haapamäki J, Turunen U, Roine RP, Färkkilä MA, Arkkila PE. Impact of demographic factors, medication and symptoms on diseasespecific quality of life in inflammatory bowel disease. Qual Life Res 2009; 18: 961-9.

36. Álvarez-Ude F. Factores asociados al estado de salud percibido (calidad de vida relacionada con la salud) de los pacientes en hemodiálisis crónica. Rev Soc Esp Enferm Nefrol 2001; 14: 64-8.

37. Rebollo P, González MP, Bobes J, Saiz P, Ortega F. Interpretación de los resultados de la calidad de vida relacionada con la salud de pacientes en terapia sustitutiva de la insuficiencia renal terminal. Nefrología 2000; 20: 431-9

38. Bardage C, Isacson DG. Hypertension and health related quality of life: an epidemiological study in Sweden. J Clin Epidemiol. 2001; 54: $172-81$

39. Permanyer C, Brotons C, Ribera A, Alonso J, Cascant P, Moral I. Resultados después de cirugía coronaria: determinantes de calidad de vida relacionada con la salud postoperatoria. Rev Esp Cardiol 2001; 54: 607-16.

40. Badia X, Fernández E, Segura A. Influence of socio-demographic and health status variables on evaluation of health states in a Spanish population. Eur J Publ Heath 1995; 5: 87-93.

41. Verissimo R, Mota-Cardoso R, Taylor G. Relationships between alexithymia, emotional control and quality of life in patients with inflammatory bowel disease. Psychother Psychosom 1998; 67: 75-80.

42. Borgaonkar MR, Irvine EJ. Quality of Life measurement in gastrointestinal and liver disorders. Gut 2000; 47: 444-54.

43. Casellas F, Vivancos JL, Sampedro M, Malagelada JR. Relevance of the phenotypic characteristics of Crohn's disease in patient perception of health-related quality of life. Am J Gastroenterol 2005; 100 : 2737- 42 .

44. Blondel-Kucharski F, Chircop C, Marquis P, Cortot A, Baron F, Gendre GP, et al. Health-related quality of life in Crohn's Disease: A prospective longitudinal study in 231 patients. Am J Gastroenterol 2001; 96: 2915-20

45. Cadahía V, García-Carbonero A, Vivas S, Fuentes D, Niño P, Rebollo $\mathrm{P}$, et al. Infliximab mejora la calidad de vida en pacientes con enfermedad de Crohn fistulosa. Rev Esp Enferm Dig 2004; 96 : 369-78.

46. Yazdanpanah Y, Klein O, Gambiez L, Baron P, Desreumaux P, Marquis $P$, et al. Impact of surgery on Quality of Life in Crohn's Disease. Am J Gastroenterol 1997; 92: 1897-900.

47. Thirlby RC, Land JC, Fenster F, Lonborg R. Effect of surgery on health-related quality of life in patients with inflammatory bowel disease. Arch Surg 1998; 133: 826-32.

48. Canavan C, Abrams KR, Hawthorne B, Drossman D, Mayberry JF Long-term prognosis in Crohn's disease: Factors that affect quality of life. Aliment Pharmacol Ther 2006; 23: 377-85. 